\title{
ACCOUNTABILITY IN SPECIAL EDUCATION
}

John J. Cook, Ph.D. ${ }^{1}$

ACCOUNTABILITY AND SPECIAL EDUCATION
In somewhat the same manner that innovation and behavioral objectives were the key terms in the educators' vernacular in the 60 s, it would appear that accountability is the key concept for the 70s. One cannot help but observe that an examination of certain fashionable terms in education could be an enlightening study in and of its own.

\section{Historical Perspective}

Actually, the concept of accountability in education is not new. In the 15th century a professor at the University of Bologna was required to start his lectures at the beginning of the text and proceed sequentially through to the end during the term. The printing press was in the process of development at that time, so books as well as competent readers of them were in very short supply. If this schedule was not adhered to, the professor forfeited part of the funds he had deposited at the beginning of the term.

In England and parts of Africa during the latter part of the 19th century, a form of accountability prevailed. An award of sixpence was provided for each student who obtained a pass in an examination in the three Rs.

The Old Deluder Satan Law of the Massachusetts Bay Colony provides another example of accountability. It was assumed that the devil could be held at bay if every child learned how to read and write. Each town was required to provide this instruction. Failure to do so resulted in a five pound fine.

A more personal example of accountability is provided by Dyer (1971). While teaching English in the 1930s, he was given to understand by the principal that a certain not too well-endowed son of an influential citizen was to pass the College Board exam at a certain level, thereby allowing him to enter a prestigious college. Failure to do so carried with it the implicit threat of lack of contract renewal. Dyer proceeded to cram the student on old exam questions so that the student

1. Dr. Cook is Coordinator of Research Design and Administration, Department of Public Instruction, State of Wisconsin (Madison).

(C) Love Publishing Company, 1972 
appeared to write profoundly on the canned themes. He passed the exams and was admitted to the college of his parents' choice. However, he flunked out at midterm. As Dyer put it, "By $y_{1}$ meeting my obligation under the narrow definition of teacher accountability then prevailing, I had succeeded in preparing the student to become a failure in college."

\section{Contemporary, Perspective}

Accountability on the contemporary scene appears to have become topical through the following sequence of events. Most writers credit Leon Lessinger with initiating and pushing the concept into the awareness of both- educators and the general public. As Deputy Commissioner in the Office of Education, he felt the frustration experienced by Congress as they sought to ascertain the impact of the large sums of federal money being spent on education. With respect to Title I, ESEA, for example, it was virtually impossible to justify with any confidence the expenditures on the many projects funded under this program in order to provide some policy for future expenditures. The cost-effectiveness approach of the Department of Defense was in vogue at the time, and questions raised within the context of this approach were found difficult to answer by the Office of Education and school people. Concomitant with this trend was a rising concern on the part of local

FOCUS ON EXCEPTIONAL CHILDREN is published monthly except June, July, and August as a service to those concerned with mentally retarded and emotionally disturbed children. Subscriptions rates, $\$ 9.50$ per year. Copyright 1972 Love Publishing Company. All rights reserved. Reproduction in whole or part without written permission is prohibited. Printed in the United States of America. Second class postage is paid at Denver, Colorado.

Executive and Editorial Offices 6635 East Villanova Place

Denver, Colorado 80222

Telephone (303) 757-2579

EDITORIAL BOARD

Edward L. Meyen

University of Missouri

Richard J. Whelan

University of Kansas Medical Center
Sallie A. Keeney Senior Editor
Stanley F. Love
Publisher-

Glenn A. Vergason Georgia State University school boards across the country about the ever mounting requests for additional funds for education. About the same time, data was also becoming available to the public about the end product of the educational system, i.e., the students' actual academic achievements on a nationwide basis. Thus, it was possible to pick up almost any newspaper or newsletter and face statements of the following nature:

-4.3 million Americans are considered functionally illiterate in modern society while 18.5 million have only marginal reading skills, and 30,000 who have high school diplomas are said to be functional illiterates reading at 5 th grade level or less.

$-34 \%$ have trouble filling in an application for Medicaid.

-Rural inhabitants have a $16 \%$ illiteracy rate while those in the suburbs have a $9 \%$ rate.

In sum, Congress and the public were asking educators to be accountable, to show the public that they (the Congress and the public) were getting a "bang for their buck," and that learning was occurring commensurate with the fiscal resources being committed to the effort.

\section{ACCOUNTABILITY IN REGULAR EDUCATION}

The response of educators to the challenge of accountability, particularly in the universities, has been a wondrous phenomenon to behold. The sheer number of articles, talks and institutes on the subject which have occurred in the past year or so defies the imagination. It is apparent that accountability as a concept has struck a responsive chord in both the public and the professional educator and that it also means many things to many people. Further on in this paper an attempt will be made to pull some of these ideas together in developing an accountability and evaluation model for special education.

\section{Es ential Elements}

It would seem that the following are the essential elements of accountability as a general concept:

1. The educator must decide what he is after in terms 
of student performance and be responsible for getting these results. Typically, reading and arithmetic skills have been the focus since deficiencies have been demonstrated in these areas, since they are relatively easy to measure objectively, and since by almost any philosophical stance they can be considered basic to subsequent learnings in other content and skill areas.

2. The concept also implies streamlined management such as a concise analysis of needs and arrangement of priorities, a precise definition and description of the inputs, the processes, and the outputrelated goals of the educational endeavor.

3. Not least in importance is that the accountability process should be communicable to the consumers (i.e., the public) in an easily understood language of the particular public. That this might be a difficult chore for the educator is readily evident when one looks at the largely redundant, confusing and often irrelevant jargon which characterizes educational discourse.

4. Finally, the whole process of governance in education must be tied to a fiscal and/or time base so that the undertaking can be demonstrated to be thrifty, sensible and, in general, presenting evidence of good stewardship.

In the above, the notion of evaluation was not mentioned explicitly; however, the concept must be considered to be implicit and indeed intertwined in the whole concept of accountability. Therefore, some clarification of the similarities and differences between the two terms is appropriate at this point.

One of the better distinctions has been offered by Anderson (1971):

1. Evaluation is concerned primarily with effectiveness (the degree to which the institution or system succeeds in doing whatever it is trying to do); accountability is concerned with effectiveness and efficiency (the capacity to achieve results with a given expenditure of resources). Thus the latter is even more complex than the former, since it must encompass not only attempts to determine success but also how much it costs to obtain it and the relationship between cost and benefit.
2. Educational evaluation-though sometimes mandated in general terms by a funding agency-is largely the business and province of the education institution or system itself; and it stands to succeed to the extent that it is viewed by administrators and staff as a vehicle for program improvement. Accountability, on the other hand, carries with it the notion of external judgement and control. The advocates of accountability view this as a positive feature-the taxpayers have a right to know.

\section{Practical Approaches}

In addition to the verbal response to accountability in education, a number of practical approaches have resulted and have been implemented with varying degrees of success. The following summarize some of the major strategies which have been tried:

\section{Performance contracting.}

In this approach, the amount paid the contracting agent is tied directly to the degree of achievement of the pupil. Typically, the contractor is a commercial company complete with curriculum offerings, software and management techniques. ${ }^{*}$ Standardized achievement tests provide the criteria upon which reimbursement to the company is based. Estimates are that in 1971 between 150 to 170 school systems spent some 50 million dollars on performance contracts of various types. Performance contracting has had considerable appeal to many educational administrators who have been in the habit of purchasing services, such as transportation, food and maintenance-so why not instructional services? Teachers, however, have not been so enthusiastic since many see their professional responsibilities being circumvented by nonprofessionals. Criticisms of this approach on other grounds are not difficult to come by, many of which could well be a function of the wording of the contract. For instance, to guarantee to bring every child up to some national or local norm seems a little ridiculous since by definition half of the pupils will generally end up below and half above the norm. In addition, research has indicated that when nonschool variables are controlled, teacher competency and/or sensitivity accounts for a much greater portion of pupil achievement than the sophisticated gimmicks 
that might be used. The long-term effects of performance contracting should also be considered in the context of an observation made by Lennon (1971):

... do you remember how ... we all anguished with our astronauts as they struggled with the recalcitrant docking device? It is reported that Mission Control called the manufacturer of the device seeking his assistance and counsel only to be told, "We're sorry; that unit has gone more than 50,000 miles, and it's not under warranty anymore." One wonders for how long some of the contract learnings may be guaranteed.

\section{Turn-keying.}

This approach simply means that the program established and presumably demonstrated to be viable under the performance contract is institutionalized, i.e., becomes part of the school system and operated by its personnel.

\section{The voucher system.}

In this approach the local authority responsible for the overall operation of the educational endeavor in the community provides the parents with vouchers. The parents, in turn, decide which of the several educational alternatives available in the community is best; they submit the vouchers as the child's tuition to the school of their choice. This school then redeems the vouchers for cash from the local authority. At the moment, this approach is highly speculative as a large-scale solution. It is apparent that something analogous to this approach has been going on for years among the wealthier citizens, particularly in the New England states, who send their children to select private schools. The rationale behind the voucher system has been well stated by Jencks (1970):

Today's public school has a captive clientele. As a result, it in turn becomes the captive of a political process designed to protect the interests of its clientele. The state, the local board, and the school administration establish regulations to ensure that no school will do anything to offend anyone of political consequence. The voucher system seeks to free schools from these managerial constraints by eliminatipg their monopolistic privileges. . . . Schools which attract no applicants go out of business. But those which survive have much greater claim to run their own affairs in their own way.

\section{Incentive Retwards.}

The most verbal champion of this approach has been Kenneth Clark, a psychologist and director of the Metropolitan Applied Research Center in Washington, D.C. In practice this approach is essentially similar to the historical examples of accountability cited at the beginning of this paper. Merit (i.e., incentive) pay plans have not faired well in education. A recent investigation (unpublished) in Wisconsin revealed that out of approximately 450 school districts only nine indicated they had a merit pay plan. Closer examination of these nine revealed that the plan was on paper only and not being implemented.

\section{Problems With Incentive Rewards}

In spite of the lack of enthusiasm for the incentive pay approach, it seems to be one approach which has the potential for getting at the essence of the concern with accountability in U.S. education as it presently exists. However, before such an approach becomes a reality a number of problems have to be resolved, preferably by the parties concerned. These problems revolve around the what, who, how and by whom of accountability.

What is the public school educational system (both regular and special) to be accountable for? This question becomes crucial because, as a social institution, education is expected to do more and more. Whatever the reasonshigher expectations on the part of the public, an inflated self-image of educators regarding their capabilities, the abrogation of responsibility by other institutions-the responsibilities of educators seem to include anything and everything which can be subsumed under the taxonomic rubric of cognitive, affective and motor development. In addition to the traditional three Rs, public school educators are being held responsible (functionally speaking, at least) for effective baby sitting, good mental health of pupils, control of drug abuse, successful post school vocational and social adjustment, aesthetic appreciation, and love of country to mention but a few. It seems that, if educators are to assume these responsibilities, society should be)prepared to allocate sufficient authority and resources (both human and fiscal) in the same way it has responded to past medical and defense needs.

Who is to be held accountable for the what above? Even restricting the question to the three Rs, this question is difficult to answer since so many nonschool variables seem to account for more of the variance on the output 
indices now used than the controllable inschool variables which presumably can be manipulated. It would seem then that an incentive or merit pay plan would make sense only when these extraneous factors are taken into account when determining the reward (monetary or otherwise) the educators should receive. Sufficient evidence exists and statistical techniques are available to make at least a provisional start on preçisely what component of the pupil's learning an educator can be held accountable for and which can be the basis for incentive plans.

In answering the how of accountability, it is apparent that the basic need is for a sophisticated and reliable information system which, as a feedback device, can provide almost instantaneous reaction on the part of the educator who is being held responsible for a particular aspect of the educational enterprise. How the information system would be interfaced with some reward or incentive plan has not yet been resolved. However, it is clear that for many dedicated professional educators merely having the informational feedback readily available could constitute sufficient reward, assuming that some reasonable level of monetary reimbursement has been reached.

By whom shall the what, who and how of accountability be determined? The issues here are complex, but it seems clear that all levels and strands of educational enterprise would have to be involved-federal, state, local, the specific instructional center, the teacher, the various professional organizations, the public, the legislature and, not to be forgotten, the pupil.

\section{ACCOUNTABILITY IN SPECIAL EDUCATION}

The various elements in the preceding general discussion of accountability has direct relevance to special education for the same reasons. Parents and legislators are no longer accepting the special educators' reassurance that the child has been "diagnosed," that he is in a "program," that his teacher is "fully certified." They are in effect saying that some (usually considerable) number of dollars has been poured into the special child's education and training and that certain tangible results should be happening which bear some relation (the more the better) to the amount of money and resources invested. The response of the special educator to the accountability concern has been neither as vocal nor as varied as his regular education counterpart. The great divensity of handicapping conditions facing him and the lower expectations of the special educator could explain his slower reflexiveness. Also, it has been only within the last few years that many special education programs literally have moved out of the boiler room in the school basement and have become the recipients of sufficient resources to even attempt anything approaching exemplary programs for the handicapped. An additional contributing factor to the slower response to accountability of the special eduators could well have been that at the beginning of the 70s he was already off balance having been inundated by children with assorted learning, emotional and behavioral problems for whom regular education could or would not attempt to provide learning experiences. In any event, it would seem that the regular educators' concern with accountability at this time is very much a problem for the special educators as well.

It is pertinent to note that, as accountability becomes more a concern of special educators, the ramifications are apt to be fairly extensive because of the involvement of the various medical, social welfare, and psychological specialties in programs for the handicapped. That is, it is difficult to conceive of special educators bearing the brunt of the accountability push. The impact of accountability on these allied professions should prove interesting and, hopefully, quite beneficial to the pupils involved.

\section{Mainstreaming}

Lest the hackles of special educators rise in the face of this somewhat mild rebuke regarding their relative lack of concern with accountability, it would be pertinent to present some supporting evidence. The most obvious area where most special educators have chosen to ignore the child's best interests in relation to the cost factor is that of what is now known as mainstreaming which was researched for a number of years under the heading of efficacy studies. Cursory, yet I think convincing, reference can be made to this area.

The author obtained from the ERIC system and other sources studies on the relative merits of special versus regular class placement for the mentally retarded (MR). Those studies concerned with academic achievement used 5,665 pupils and extended over the past 12 years. The data were virtually unanimous in indicating that the higher level MRs (IQ 70+) benefited academically in the regular class. Studies on social adjustment using 749 pupils and extending back 15 years yielded equivocal results overall.

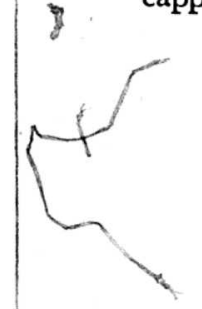


The statements which follow are representative of the feelings of a large body of professionals and have yet to be seriously heeded by the majority of special education policy makers and practitioners (Lilly, 1970):

. . . Notwithstanding the many obvious and valid criticisms of studies comparing special versus regular class membership, it has yet to be demonstrated that the special class offers a better school experience for retarded children than does regular class placement (Blatt, 1960, pp. 53-54).

... While the special classes may be administratively convenient, there is no doubt that the procedure has made special education special, isolated it, and in so doing perpetuated the isolation and attending mysticism which has stood in the way of special education development (Fisher, 1967, p. 29).

. . . Let us stop being pressured into continuing and expanding a special education program that we know to be undesirable for many of the children we are dedicated to serve (Dunn, 1968, p. 5).

... Special education is helping the regular school maintain its spoiled identity when it creates special programs ... for the "disruptive child" and the "slow learner" many of whom, for some strange reason, happen to be Black and poor and live in the inner city (Johnson, 1969, p. 245).

... There has been no reliable evidence produced to indicate that differential benefits, either social or academic, àccrue to regular studènts as a result of either the exclusion or inclusion of exceptional students in regular classes (Christoples and Renz, 1969, p. 373).

Recent analysis of data from two Title VI projects (Wausau, and Janesville, Wisconsin) strongly indicated the increased benefits for younger, higher level MRs in - the regular as compared to the special class.

While mainstreaming can and has (Bruininks and Rynders, 1971) been criticised as an alternative to special class placement on a númber of grounds, it does seem that the signal to noise ratio is large enough to warrant serious consideration by administrators as a major alternative.

Finally, the recent spate of court cases challenging special class placement of retarded children (Ross, et al.,
1971) suggests that special educators should start mainstreaming more intensively or the courts and legislators will do it for them. This latter action would be unfortunate for the pupils if attempted unilaterally. In the final analysis, considerable understanding and feeling for these children has been attained over the years by special education personnel and should not be ignored in planning and implementing programs for these pupils.

In a somewhat different vein, it is patently evident that it is impossible to talk about special education without considering the special education teacher training institutions. Up until now, the accountability push has left them relatively unscathed. One need not be clairvoyant to see that the many requirements for graduation, accreditation, and certification which have a time or clock base will not suffice. Instead, accountability as it affects the training institutions will have to be in terms of demonstrated teacher competency.

\section{STUDY OF APPLIED ACCOUNTABILITY}

The following study provides an example of applied accountability in special education. One of the original objectives of the study done in Wisconsin (Cook and Blessing, 1970) was to conduct a comparative cost analysis of classroom units with increased educable enrollment utilizing teacher aides versus classroom units with traditional enrollments and no aides. Of interest also was a cost-efficiency analysis of the extreme case of increased class size (class size on entering project plus 50\%) without an aide versus the standard size with an aide.

\section{Cost Analysis Models}

Several approaches to the cost analysis were considered. In all instances certain assumptions had to be made and, if one could live with these assumptions, then the analysis made sense. The first approach considered was the "service" model. This model assumes that, if a child can be brought into contact with and spend most of his time with certain professional and paraprofessional personnel, all appropriately certified, then all sorts of positive things will start happening to him. An effective cost analysis under these circumstances should demonstrate that additional children, can be "serviced" without an undue increase in the cost per child. The concern of the present project, under this model, was to show that the cost per pupil in an increased size class with an aide 
Table 1. Raw Data for Cost Analysis Based on the Two Semesters in the 1967-68 School Year
No Aides

\begin{tabular}{|c|c|c|c|c|c|c|c|c|c|}
\hline & & $\begin{array}{c}\text { One Year } \\
\text { Cost Per } \\
\text { Pupil }\end{array}$ & $\begin{array}{l}\text { Class Ave. } \\
\text { One Year } \\
\text { Grade Level } \\
\text { Achievement }\end{array}$ & $\begin{array}{l}\text { Class Ave. } \\
\text { Cost/Year } \\
\text { Achievement }\end{array}$ & $\begin{array}{l}\text { Ave. } \\
\text { Size }\end{array}$ & $\begin{array}{c}\text { One Year } \\
\text { Cost Per } \\
\text { Pupil }\end{array}$ & $\begin{array}{l}\text { Class Ave. } \\
\text { One Year } \\
\text { Grade Level } \\
\text { Achiemement }\end{array}$ & $\begin{array}{l}\text { Class Ave. } \\
\text { Cost/Year } \\
\text { Achievement }\end{array}$ & $\begin{array}{l}\text { Ave. } \\
\text { Size }\end{array}$ \\
\hline 눙 & 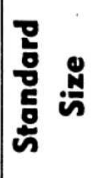 & $\begin{array}{c}\$ 1,075^{*} \\
923 \\
934\end{array}$ & $\begin{array}{c}\text { (mos.) } \\
7.0 \\
6.0 \\
4.7\end{array}$ & $\begin{array}{r}\$ 1,536 \\
1,538 \\
1,987\end{array}$ & $\begin{array}{l}10 \\
11.5 \\
11.5\end{array}$ & $\begin{array}{r}999 \\
1,310\end{array}$ & $\begin{array}{c}\text { (mos.) } \\
2.0 \\
4.0\end{array}$ & $\begin{array}{r}\$ 4,993 \\
3,275\end{array}$ & $\begin{array}{l}11.5 \\
10.5\end{array}$ \\
\hline 2 & 总 & $\$ 753$ & 3.0 & $\$ 2,510$ & 16.5 & $\begin{array}{r}\$ 41 \\
995 \\
1,293\end{array}$ & $\begin{array}{l}3.0 \\
3.7 \\
3.0\end{array}$ & $\begin{array}{r}\$ 2,802 \\
2,690 \\
4,308\end{array}$ & $\begin{array}{l}18.5 \\
17.0 \\
13.0\end{array}$ \\
\hline$\frac{\mathscr{\Xi}}{\square}$ & 홓 & $\begin{array}{r}\$ 969 \\
657\end{array}$ & $\begin{array}{l}2.3 \\
4.3\end{array}$ & $\begin{array}{r}\$ 4,215 \\
1,528\end{array}$ & $\begin{array}{l}14.5 \\
15.0\end{array}$ & $\begin{array}{r}\$ 1,439 \\
840 \\
1,199 \\
1,006\end{array}$ & $\begin{array}{l}2.3 \\
3.3 \\
5.7 \\
2.0\end{array}$ & $\begin{array}{r}\$ 6,257 \\
\mathbf{2 , 5 4 5} \\
\mathbf{2 , 1 0 3} \\
\mathbf{5 , 0 3 0}\end{array}$ & $\begin{array}{l}10.5 \\
15.5 \\
12.5 \\
13.5\end{array}$ \\
\hline 르 & 造 & $\begin{array}{r}\$ 611 \\
601\end{array}$ & $\begin{array}{l}3.7 \\
2.3\end{array}$ & $\begin{array}{r}\$ 1,651 \\
2,613\end{array}$ & $\begin{array}{l}17.5 \\
22.0\end{array}$ & $\begin{array}{r}\$ 677 \\
713 \\
782\end{array}$ & $\begin{array}{l}3.0 \\
4.0 \\
4.3\end{array}$ & $\begin{array}{r}\$ 2,257 \\
1,783 \\
1,819\end{array}$ & $\begin{array}{l}21.5 \\
19.5 \\
20.5\end{array}$ \\
\hline
\end{tabular}

"Based on teacher salary, aid salary (when opplicable), administrative costs, transportation, books, instructive equipment,

attendance, operational, maintenance and fixed costs, and school lunch. Exclusive of salaries the average cost per pupil was $\$ 192$.

was not significantly greater than the standard sized EMR class without an aide.

The raw data for this and succeeding analyses is contained in Table 1. Summary data for the above concern was:

\begin{tabular}{|c|c|c|c|}
\hline \multicolumn{2}{|c|}{ No Aides } & \multicolumn{2}{|c|}{ Aides } \\
\hline $\begin{array}{c}\text { Standard } \\
\text { Size }\end{array}$ & $\begin{array}{l}\text { Increased } \\
\text { Size }\end{array}$ & $\begin{array}{l}\text { Standard } \\
\text { Size }\end{array}$ & $\begin{array}{c}\text { Increased } \\
\text { Size }\end{array}$ \\
\hline$\$ 912$ & $\$ 655$ & $\$ 1,132$ & $\$ 883$ \\
\hline
\end{tabular}

As the data shows, it costs about the same to serve a pupil one year in a standard size class without an aide (\$912) as it does in a class increased in size using an aide (\$883). Indeed, the differential ( $\$ 29$ per pupil) which did exist favored the latter type of class.
An unknown here is the value which resides in providing special education services to EMR children. If this value is large, then the dollar signs do not adequately reflect the worth of being taken off the EMR waiting list as was the case with one-third of the children in the increased size classes.

The second approach to the cost analysis was to use what might be called a "commerce" model. Here it is assumed that one knows what he wants to attain or produce and has limited resources to do so. Thus, the concern is to attain or produce a given unit of what is desired at the least possible cost. In the present study, the assumption was made that academic achievement was trying to be maximized and a given unit of this achievement should be obtained at the lowest possible cost. 
The procedure in obtaining a cost-achievement index for the 1967-68 school year was as follows. For a given class, teacher and aide (where applicable) salaries were obtained and added to the cost of administration, transportation, books, instructional equipment, attendance, operations, maintenance and fixed costs. The number of pupils in each class was averaged for $T_{2}$ (September, 1967 ) and $T_{3}$ (June, 1968). The average cost per pupil in each of the 20 classes in the project was then calculated (see Table 1).

The gain in achievement on the three WRAT subtests was calculated for the 1967-68 school year. The average gains on the three subtests was obtained. These figures are shown in the cells of the design in Table 1.

A meaningful cost-achievement index should be calculated on a common base. The common base selected was the academic school year of ten months. That is, using our data, the question was, "How much does it cost on the average in each class for an EMR pupil to achieve ten months?" The formula used was:

\begin{tabular}{l}
$\begin{array}{l}\text { Average cost per pupil in } \\
10 \text { month'/class }\end{array}=\frac{10 \text { months of achievement }}{\begin{array}{l}\text { Cost to achieve } 10 \text { months' } \\
\text { Actual average achievement } \\
\text { in } 10 \text { months }\end{array}}$ \\
$\begin{array}{l}\text { go: Cost to achieve 10 (an unknown) } \\
\text { months' growth }\end{array}=\frac{10 \text { (Average cost per pupil }}{\text { in } 10 \text { months) }}$ \\
\hline
\end{tabular}

The formula was calculated for each of the 20 classes and the results are displayed in the cells of the design in Table 1 . The cost to move a pupil 10 months in achievement varied considerably from $\$ 1,510$ to $\$ 6,257$ (see Table 1). These figures appear substantial considering that in the regular classes in Wisconsin during 1967-68 (using the same cost items) the cost per pupil was $\$ 624$. This comparison is meaningful if the not unreasonable assumption can be made that this average regular class pupil gained 10 months in achievement in one school year. The cost-achievement index developed here could be considered as simply another dependent measure and was analyzed within the general research design of the study.
The treatment effects of interest were:

Increased size, without aide (Cost-\$2,258)

Standard size, without aide (Cost-\$2,610)

Increased size, with aide (Cost-\$2,161)

Standard size, with aide (Cost-\$4,033)

Statistical analysis indicated that no evidence existed for an administrator to choose between use or nonuse of teacher aides without regard to class size or between increasing class size $50 \%$ or not, regardless of whether an aide was used. The only a priori contrast which was statistically significant was that which indicated that the standard size class using an aide was more expensive than the other three combinations in providing for ten months of growth in academic achievement.

Table 2 shows the two-way tables of the means of the cost achievement data for the three factors in the designclass, aides and size. These data have primarily heuristic value since statistically significant differences were not obtained. Thus, the average cost for one year of achievement across all classes was $\$ 2,872$. The least expensive combination was not aides in the primary classes $(\$ 1,892)$, while the most expensive was aides in the standard classes $(\$ 4,033)$. Since these are only two-way tables, the third factor not shown in each table has been collapsed.

While a number of criticisms can be leveled at a study of this type-using the WRAT with MRs and in the way it was used, averaging, using grade levels, limited generalization, the various assumptions made-one has to consider the alternatives in decision making. In a word, none. Therefore, aides for EMR classes were funded only when class size was increased, i.e., the greatest "bang for the buck" could apparently be achieved using this strategy. In retrospect, it was fortunate that the field supervisors' interocular tests did, not contradict the statistical tests.

\section{ACCOUNTABILITY-EVALUATION CONCERN}

An article by Proger (1971), written in a somewhat humorous, critical yet truthful manner, soundly drubs the proliferation of evaluation models in education. Using the Peter Principle (Peter and Hull, 1969) as his "model," Proger advanced what he called the Proger Principle: "In a conceptual hierarchy every concept (i.e., evaluation models) eventually rises from a specific levêl of applicability to a general level of functional incompetence 
Table 2. Two-Way Tables of Means and Frequencies of Cost-Achievement Data for the Three Factors of Class, Aides and Size. The Means Are Based on Class Averages of the Dollar Cost of an EMR Pupil Achieving One Academic Year (10 Months)

a)

\begin{tabular}{|c|c|c|c|}
\hline Aides & Primary & Intermediate & Across Class \\
\hline$\overline{\text { Aides }}$ & $\$ 3614$ & $\$ 3113$ & $\$ 3322$ \\
\hline No & $\begin{array}{r}1892 \\
\text { (4) }\end{array}$ & 2502 & 2197 \\
\hline $\begin{array}{l}\text { Across } \\
\text { Aides }\end{array}$ & $\begin{array}{r}2849 \\
\text { (9) }\end{array}$ & $\begin{array}{r}2891 \\
\text { (11) }\end{array}$ & $\begin{array}{r}2872 \\
(20)\end{array}$ \\
\hline
\end{tabular}

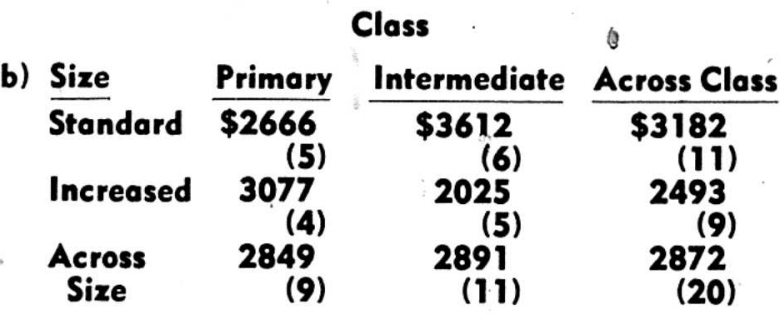

Aides

\begin{tabular}{|c|c|}
\hline Size & Standard \\
\hline Aides & $\$ 4033$ \\
\hline No Aides & ( \\
\hline $\begin{array}{c}\text { Across } \\
\text { Size }\end{array}$ & $\begin{array}{r}3322 \\
(12)\end{array}$ \\
\hline
\end{tabular}

\begin{tabular}{ccc} 
Increased & Across Aides \\
\cline { 1 - 1 }$\$ 2161$ & & $\$ 3182$ \\
$(5)$ & & $(11)$ \\
2258 & & 2493 \\
$(3)$ & & $(9)$ \\
2197 & & 2872 \\
$(8)$ & $(20)$ \\
& &
\end{tabular}

through 'logical analysis.' " It is difficult to argue with the basic notions expressed here, although one wonders where those evaluation ideas and models are which at one time apparently had a "șpecific level of applicability." Perhaps the answer lies in Proger's plea to do something with the existing models.

With due trepidation then, the remainder of the section will describe an approach to (model of ?) the accountability-evaluation concerri which has been in use in the evaluation of Title VI projects in Wisconsin with some modifications for the past three years. The model was generated in response to a number of needs which became apparent shortly after funding for ESEA Title
VI-A began in 1967. These needs took the following forms:

1. Even for the simplest projects, the amount and ambiguity of verbiage generated in writing up the projects very nearly plugged the fragile communication channels between the SEA and the LEA. The writing model used was that of research and was written by local and university people, many with little real expertise in research. Actually, the research model would have been inappropriate regardless of authors' expertise, since Title VI was a very action-oriented program.

2. Initially, the out-of-pocket cost to the LEAs in getting the project funded was averaging $20 \%$ of the total grant award. A fivefold increase in one's investment is not a bad return, but that was not the name of the game.

3. Since Title VI has been by definition a childcentered program, there has always been, implicit at least, a concern with some measurable index of the impact of its projects on the children, a concern now considered the major output in the present accountability push. There was a need then to both index and organize the data collected in some coherent and easily interpretable manner.

4. Educators-special or regular-have not been noted for their openness to change or to innovation. It was apparent that the additional funds under Title VI would make available many new techniques and materials. The change in teacher behavior which could be attributed to inservice meetings and didactic presentations by university personnel was negligible. As an alternative (and if teacher and administrative behavior was to be amenable to change) some means of accentuating the feedback to these people on crucial variables would have to be built into any evaluation system.

;

In summary, the needs for simplicity and inexpensiveness of project write-up and evaluation, coherence and simplicity in data collection, as well as meaningful feedback to the on-line and administrative personnel at the various levels dictated the form of the accountabilityevaluation model which has been used. These needs have 
Figure 1.

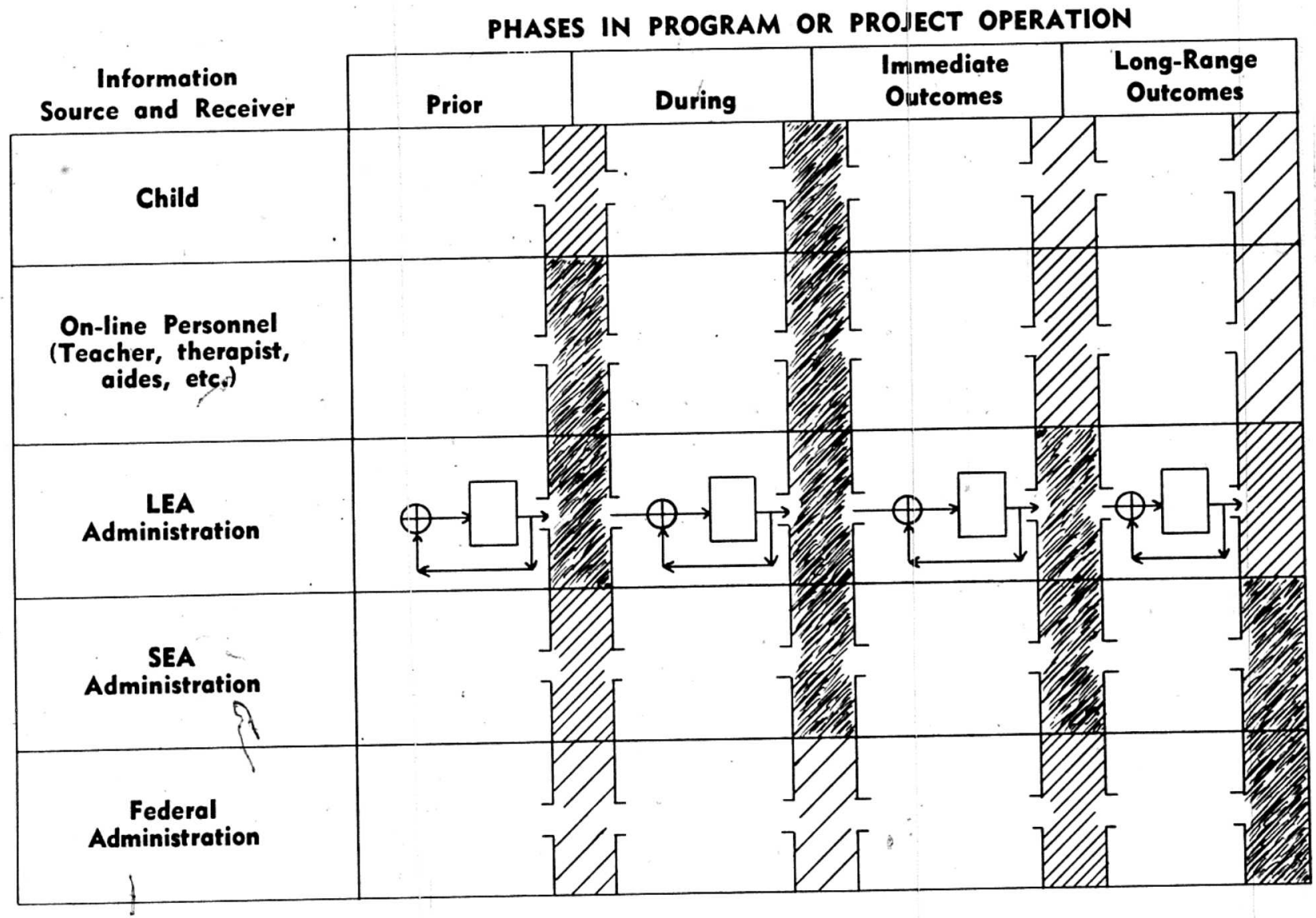

Data or information matrix with accountability depending on information flow (from evaluative efforts) in the vertical columns at each stage of

not all been met in an optimal fashion. More work needs to be done in conceptualization and, most important, in the how of implementation.

\section{Evaluation-Accountability Model}

In this section an attempt is made to delineate the relationships between evaluation and accountability and to depict some of the informational feedback processes which are a necessary aspect of evaluation and accountability. The implications of the moclel are not restricted to special education nor to project operation alone. project operation. (The darker the column shading, the greater the density of information flow.)

Rather, it is felt the model has relevance to regular education and to long-term program operation where a specific time span can be specified.

The basic evaluation model is two dimensional with data and information source and receiver on the vertical axis and the phases of project operation on the horizontal axis (see Figure 1). Since feedback loops, communication channels, etc. are an intrinsic part of the accountability-evaluation model as conceptualized, more dimensions, lines, circles, arrows, and so forth could be added to the model. Such an approach tends to be confusing for the reader so an attempt will be made to let the written 
word carry the brunt of the communication, thereby keeping additions to the schema at a minimum.

Certain assumptions, indeed observations, are implicit, in this model. First, it can be argued that evaluation can occur independent of accountability. That is, with unlimited resources project. and program goals can be attemped and often achieved without regard for any consideration of benefit which might accrue. In Figure 1, evaluation can be considered to be a process occuring along the horizontal axis and can be characterized by the contemporary evaluation terms used, such as planning (prior), formative (during), and summative (immediate and long-range outcomes). At each phase of project operation, a negative feedback loop is considered to exist with the responsibility of the evaluator being that of generating information for the project operator regarding the extent of goal attainment. In Figure 1, the feedback loops are depicted for the LEA administrator only. Feedback loops can be considered to exist in the other cells of the schema.

For an expanded version of the feedback loop, based on the prior phase in Figure 1, see Figure 2. Several features of the formulation can be noted based on experience with this model. The model seems to be general enough to encompass: at a very broad level all the activities in state and federally funded programs in special education. At the same time, it is apparent that every project and program is unique to a certain extent, and the evaluator has to do considerable digging and structuring to determine in reality who the responsible personnel are and what the objectives are. Once the objectives have been explicated in operational terms, the evaluator is then faced with the problem of indexing or measuring as well as summarizing (statistics) where necessary in terms meaningful to the project personnel. Toward these ends, a bank of indices and measurement techniques has been computerized which allows easy retrieval of the relevant indices for a particular project. As depicted, in Figure 1, the model provides data from a number of sources identified by thê various cells. The data collection regarding goal attainment occurs along a time base. The time required can be reduced by pouring more money into given phases or cells. Conversely, reducing the amount of funds available at a given point will, in general, increase the time required for maximum goal attainment and data collection.

It has been noted that evaluation can occur independently of accountability. On the other hand, it is maintained that accountability cannot occur independently of evaluation. In Figure 1, an attempt is made to depict these features in the model. Evaluation is first and foremost concerned with making sure interpretable information is generated. One function of this information is to allow the project personnel to develop reasonable

Figure 2. Expanded Feedback Loop

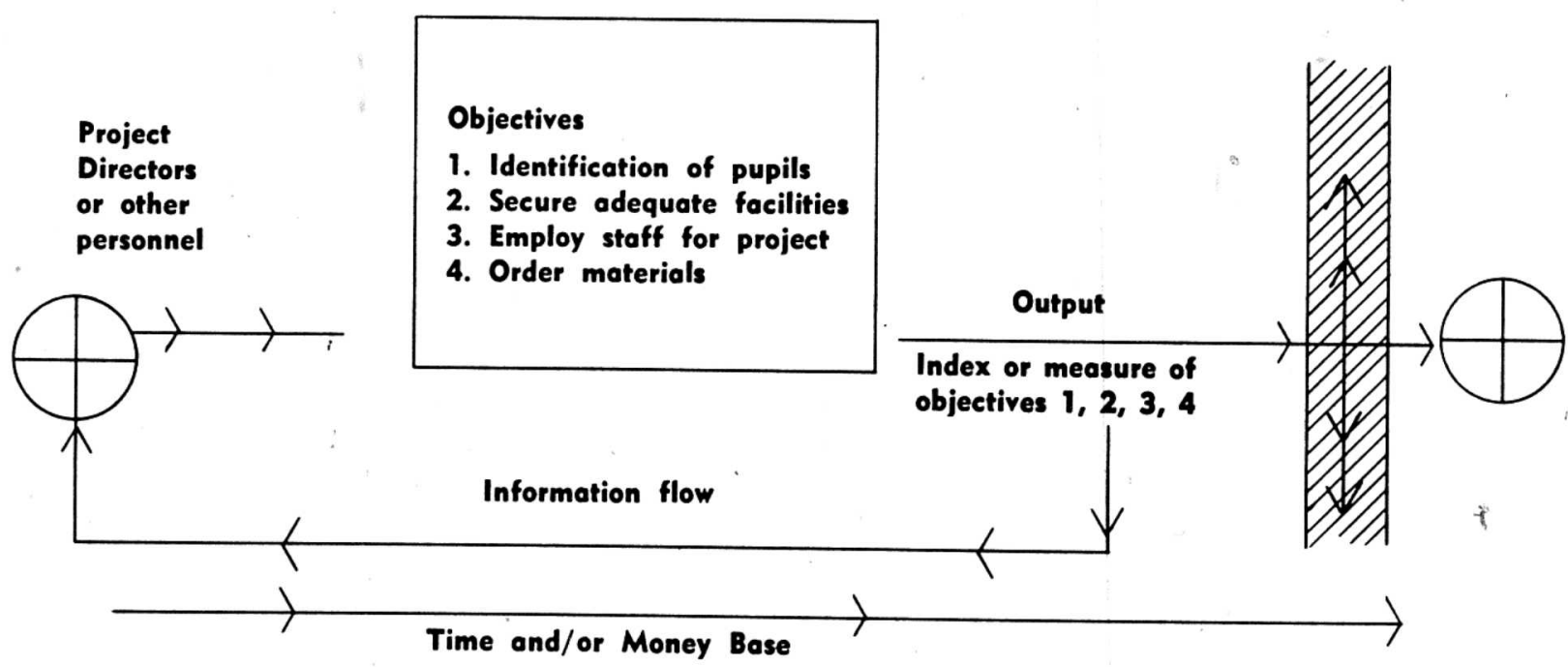


FIGURE 3.

TITLE VI EVALUATION FORMAT-PLANNING PHASE

PROJECT TITLE

DISTRICT

PROGRAM ADMINISTRATOR

MAIN PURPOSE OF PROJECT
FORMAT DUE:

Return to:

\section{INSTRUCTIONS FOR USE OF THIS FORMAT}

\section{PRELIMINARY EVALUATION}

This format is designed to aid you in evaluating the effectiveness of this project as well as to provide a feedback: system for evaluating Title VI programs in Wisconsin. It is to be filled out during the planning or early operational phase of the project so that methods of evaluating the effectiveness of the program in meeting its objectives can be designed into the program.
Section I of the format deals with the planning and organizational phase of the project from the time you applied for Title VI funding to the day the program actually began. Please summarize the procedures you used to prepare for this project and rate the success of each step on a scale of 1 to 7 with a brief explanation for the rating. Of special interest are problems which you encountered in beginning this project and strategies you used to meet these problems. Is there any way these problems could have been avcided? What could have been improved?

\section{EXAMPLES:}

Planning and organization processes necessary to begin this project.

\section{SECTION I PLANNING PHASE}

Rating Scale-Success in implementing this procedure

Reason for rating

\begin{tabular}{|c|c|c|c|c|}
\hline Identification of children to be served. & $\begin{array}{l}\text { Low } \\
12\end{array}$ & $\begin{array}{l}\text { Medium } \\
3 \quad 4 \quad 5\end{array}$ & $\begin{array}{l}\text { High } \\
67\end{array}$ & $\begin{array}{l}\text { Disagreement between project leader and school } \\
\text { psychologist on selection of criteria. Resolved by } \\
\text { consultation with DHC supervisor. }\end{array}$ \\
\hline cure adequate & 12 & 345 & 67 & $\begin{array}{l}\text { Two classrooms and staff office obtained in centrally } \\
\text { located school. Necessary remodeling completed by } \\
\text { Sept. } 1 \text {. }\end{array}$ \\
\hline $\begin{array}{l}\text { and } \\
\text { ker). }\end{array}$ & 12 & 345 & 67 & $\begin{array}{l}\text { Qualified teacher and aide employed. Part-time per- } \\
\text { sonnel not available for as many hours per week as } \\
\text { originally planned. }\end{array}$ \\
\hline $\begin{array}{l}\text { rder educational material and equipment } \\
\text { eded by project. }\end{array}$ & 12 & 34 & & $\begin{array}{l}\text { Slow delivery of supplies and late availability of Title } \\
\text { VI Funds meant many items not here by September } \\
\text { 1. }\end{array}$ \\
\hline
\end{tabular}

Other relevant concerns in this period may be arranging for transportation, dissemination of information about project, establishing budgetary limitations and procedures, ordering supplies, goals and objectives in a given phase based on the evaluative information from the previous phase of pi ject operation. For instance, if instructional material or identification of the appropriate children cannot be attained as expected in the prior phase, then modifications of objectives in both the operational and output phases can be expected and, unless considered, will make a mockery of the original project proposal. In the model this linear, horizontal transfer of information without a vertical transfer up and down the columns to the child and to the federal administration precludes the first condition for accountability. If this vertical transfer occurs, then the first condition of accountability is met. In Figure 1, the shading of the columns depicts the hypothe- providing inservice training, setting project goals. If the project is now in operation please write a short summary of the organizational phase.

sized density of information flow to the various levels of senders and receivers. For example, during the prior phase the information generated through the evaluation process is of interest primarily to the on-line personnel and LEA administrators, is of lesser interest to the child and the state administrators, and is of little interest to the federal administration. It should be noted that the information generated is assumed to be of some interest to all levels. An attempt: is also made to illustrate some of these notions in the diagram of a negative feedback loop from the model (see Figure 2). Here the arrows clearly show the flow of information to the subsequent phase as well as into the vertical channels. In the second aspect of accountability, the extent of goal attainment and the 
s

acquired information has to be related to the resources expanded in both reaching the goal and in acquiring the information that the goal has been reached. The time and/or money base to the feedback diagram is an attempt to depict this relationship.

Figure 3 depicts a data collection format which attempts to generate feedback upon which the project director and/or teacher can base their appraisal of goal attainment and consequently take appropriate corrective action. In Figure 3, the format is the prior or planning phase of the project only. Instructions and format for the project objectives phase are contained in Figure 4 , while Figure 5 depicts the operational phase.
Finally, it is assumed that the citizen-taxpayers can be in a position to observe the process shown in the model and make judgement about their effectiveness. However, if the information flow is limited or not meaningful, the citizen is not in a position to make a decision about the adequacy of use of the community's resources. Under these circumstances accountability is not possible.

\section{CONCLUSION}

As noted previously, much more work needs to be done in a refinement of the conceptualization of the model based on empirical evidence as well as on the implemen-

FIGURE 4.

\section{SECTION II PROJECT OBJECTIVES}

Section II of the format deals with objectives of the project Many of these objectives have been listed in the proposal you submitted in requesting funding; however, you may wish to be more specific or detailed here so that the objectives are more precise and easier to measure. At this time you will be able to complete only the left hand column but it is important that you specify the objectives at the beginning of the program and plan now for methods of measuring your success at the end of the project.

Part A asks for objectives for the children in the program; what changes do you hope will occur in their academic achievement, behavior, attitudes, etc. If you know what criteria you will use as evidence, please cite them here as in example 1.
Part B focuses on other goals which are to be met by the end of the project. These would include objectives to be accomplished through inservice training for staff and parent participation, curriculum development, etc. Again please indicate, if possible, how you will evaluate the success or failure of each goal.

Part C is concerned with long range objectives for the children and program changes which you would like to occur because of the project. These objectives will probably not be realized immediately but should be important and enduring changes which are due to the impact of this project on the children or on the educational establishment.

EXAMPLES:

\section{SECTION II PROJECT OBJECTIVES}

Rating Scale

Success in reaching objective
Evidence which justifies this rating. Results of tests, rating scales, parent surveys, teacher evaluations, student performance, anecdotal reports, etc.

Part A. As a result of this project children will: Medium Improve their reading ability. ardized reading test will be used to measure the change.

\begin{tabular}{lllll} 
Low & \multicolumn{2}{l}{ Medium } & High \\
12 & 345 & 67
\end{tabular}

$\begin{array}{llllllll}1 & 2 & 3 & 4 & 5 & 6 & 7\end{array}$

Part B. Other Objectives:

Inservice training for elementary teachers will improve their ability to help children returning to regular classrooms from project's learning center.

$\begin{array}{lllllll}1 & 2 & 3 & 4 & 5 & 6 & 7\end{array}$

Part C. Long range objectives:

Development and evaluation of instructional materials for elementary children with special learning disabilities.

$\begin{array}{lllllll}1 & 2 & 3 & 4 & 5 & 6 & 7\end{array}$

YOU DO NOT HAVE TO RATE AND CITE EVIDENCE AT THIS TIME. Please return this section of the format now as you will be given an opportunity to modify objectives and rate their attainment at a later date. 
FIGURE 5

\section{SECTION III PROJECT OPERATION}

This section of the format should provide an overview of the This section of the format should provide an the beginning of the program, what happened to them during the program and what the results were. At the conclusion of the project you will be the results were. At the conclusion of the prectiveness of each procedure in achieving its objective but also the degree to which each procedure was actually implemented during the project. This should make was actually implemented during the prou to establish cause and effect relationships between what took place during the project and the end results. Pertinent information will include staff for the project and their responsibilities, number of children and criteria for selecting them for the project, abilities and characteristics of the children when they enter the program (as shown by pretest measurements or base line behaviors), and a summary of procedures which will be used to reach the objectives specified in Section II. Somes of the concerns will deal with administrative functions and others will deal with program implementation. You may group the functions if you wish and ask the person directly responsible for carrying out the program to summatize the instructional procedures. An additional page may be needed to describe some programs; for example, a program using behavior modification techniques will need extra space to give examples of rewards and contingencies.

It is not necessary to rate any of the operational phases of the project at this time but you may if there are some processes which will occur only in the beginning of the project and therefore are already completed. You will have an opportunity to indicate procedural modifications and to rate the various aspects of program operation at a later date.

\section{EXAMPLES:}

Methods and procedures being used to achieve goals and operate project

\section{SECTION III OPERATIONAL PHASE}

Rating Scale

(Degree of implementation or success )

\begin{tabular}{|c|c|c|c|c|}
\hline $\begin{array}{l}\text { 1. Fivaluate entering abilities and behaviors of stu- } \\
\text { dents. Instrument to be administered before } \\
\text { October } 15 \text { are }\end{array}$ & $\begin{array}{l}\text { Low } \\
1,2\end{array}$ & $\begin{array}{lll}\text { Medium } \\
3 & 4 & 5\end{array}$ & $\begin{array}{l}\text { High } \\
67\end{array}$ & \\
\hline $\begin{array}{l}\text { 2. Prepare individualized instructional programs on } \\
\text { the basis of diagnostic evaluation. }\end{array}$ & $1 \quad 2$ & $\begin{array}{lll}3 & 4 & 5\end{array}$ & 67 & \\
\hline $\begin{array}{l}\text { 3. Coordinate schedules of children in program on } \\
\text { a part-time basis. }\end{array}$ & $\begin{array}{ll}1 & 2 \\
-\end{array}$ & 345 & 67 & \\
\hline $\begin{array}{l}\text { 4. Initiate parent program through teacher-parent } \\
\text { conferences and monthly meetings. }\end{array}$ & 12 & 345 & 67 & \\
\hline
\end{tabular}

tation of the model. For instance, in special education how many children have a say in goal setting and obtain knowledge about the extent of their attainment of these goals? With respect to the on-line personnel, are appropriate feedback mechanisms built into the classroom situation and is the extent of goal attainment communicable in information readily understandable to LEA and SEA administrators? The formats depicted in Figures 3, 4 and 5 indicate some of the attempts to provide feedback to the LEA directors of Title VI projects. They also provide a means of communicating to on-line and SEA personnel regarding project operation and outcomes. SEA and the federal agencies have always had some form of evaluation and dissemination going on, yet the recent - furor over accountability suggests that these efforts have

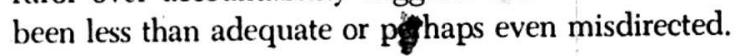

\section{REFERENCES}

Anderson, S.B., Accountability: LaNouvelle Vogue. Proceedings on conferences on accountability sponsored by E.T.S., March, 1971.

Bruininks, R.H. and Rynders, J.E. Focus on Exceptional Children, September, 1971.

Cook, John J. and Blessing, K.B. "Class Size and Teacher Aides as Factors in the Achievement of the Educable Mentally Retarded," Bureau Memorandum, Vol. XIII, No. 1, Autumn, 1971. Jencks, C. "Education Vouchers," New Republic, July, 1970.

Lennon, R.T. "Accountability and Performance Contracting." Address to AERA, February 5, 1971.

Lilly, S. "Special Education: A Teapot in a Tempest," Exceptional Children, September, 1970.

Peter, L.F. and Hull, F. The Peter Principle: Why Things Alvays Go Wrong. New York: William Morrow, 1969.

Proger, B.B. "Program Evaluation: The Model-Building Game," Journal of Learning Disabilities, Vol. 4, No. 6, 1971.

Ross, S.L., Deyoung, H.G. and Cohen, J.S. "Confrontation: Special Education Placement and the Law," Exception Education, September, 1971. 


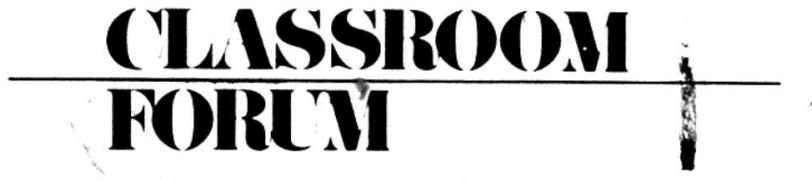 \\ Edited by Austin J. Connolly, University of Missouri}

\section{PROBLEM 15}

I teach a special class that is located in a large clementary school. My principal doesn't understand special education. What should I do?

Unfortunately, most principals and many superintendents and supervisors do not understand special education; some take a negative or indifferent attitude toward it. I believe that there are several steps you can take to help your principal acquire a better understanding of special education.

1. Encourage him to read some of the most recent professional books, bulletins, research, and survey reports on special education.

2. Request a conference with him at which time you explain the aims, objectives, and procedures of teaching in the special class. You may also acquaint him with the subject matter and other materials that you plan to cover in this class.

3. Invite him into the classroom to observe your pupils at work. Point out the varied ages, interests, ability levels. Show him their present work along with samples of their previous work as well as their cumulative records before entering special education.

4. Plan to give assembly programs, have exhibits of their best work, and initiate "open house" for the entire school body and the general public to let them know what your special class can do.

5. Invite your principal to attend some of your workshops and inservice training courses when you are having an especially interesting and well-informed consultant present.

6. Try to interest him in availing himself of one of the three-day, two-week, or six-week summer courses which are offered in special education at most colleges and universities.

7. Your students are your best "salesmen." If you inspire and motivate them to be prompt and regular in attendance, neat and clean in appearance, and well-behaved both in and out of the classroom, you will have a lot going in your favor. Your principal will be compelled to judge the program by the pupils.

8. If he is not yet convinced of the worth of the program, do some research of the activities and job placements of former special education students to learn how they are contributing to society.

We thank Gertrude C. Stitt, Coordinator of Special Education, Harnett County Schools, Lillington, North Carolina, for submitting the above suggestions.

In applying these and other ideas, the classroom teacher must remember that a principal's role is difficult and multifaceted. It is nearly impossible for him to attain expertise in every curricular program. Realizing this, the teacher might offer to provide the principal with selected material designed for a succinct orientation to special education. In addition, the teacher may offer to provide him with a monthly, one-page resume of her class activities.

Most administrators would welcome the opportunity to become familiar with special education if the knowledge could be attained in a nonthreatening atmosphere without a major investment of time. Although the classroom teacher must make the extra effort, having the principal on her team will ultimately lead to multiple benefits for the special education program.

\section{PROBLEM 17}

I have great difficulty getting my special class to work productively in small groups. Do you have some suggestions that would facilitate group work?

All readers are invited to send their solution to Problem 17. The April, 1972 issue will summarize contributions by readers. Complimentary subscriptions will be awarded each month for the best solutions. Send your response to the Editorial Offices, Focus of Exceptional Children, 6635 East Villanova Place, Denver, Colorado 80222. 


\section{INDEX • VOLUME 3}

\section{Author Index}

Atkinson, Anna Pearl (September 1971)

Barksdale, Mildred W. (September 1971)

Bruininks, Robert H. (September 1971).

Cejka, Joyce (Monthly except September and February)

Connolly, Austin J. (March through February)

Conover, Darlene (January 1972)

Cook, John J. (February 1972)

Fendley, Amy Lee (October 1971)

Grosenick, Judith K. (October 1971)

Hall, R. Vance (December 1971)

Heiss, Warren E. (April 1971)

Mischio, George S. (April, 1971)

Peter, Laurence J. (May 1971)

Ray, Henry W. (November 1971)

Rynders, John E. (September 1971)

Scagliotta, Edward G. (May 1971)

Shepard, George (March 1971)

Wedemeyer, Avaril (Monthly except September and February)

Wisely, Forrest G. (May 1971)

Wood, Mary Margaret (October 1971)

\section{Subject Index of Articles}

The early education of handicapped children (March 1971)

Designing curriculum for the educable mentally retarded (April 1971)

The prescriptive teaching system: a teacher education program (May 1971)

Developing the process of thought with the learning disabled child (May 1971)

Missouri conference in the categorical/non-categorical issue in special education (May 1971)

Alternatives to special class placement for educable mentally retarded children (September 1971)

A resource room approach to instruction for the educable mentally retarded (September 1971)

Integration of exceptional children into regular classes: research and procedures (October 1971)

Rutland center: a community psycho-educational center for emotionally disturbed children (October 1971)

Media for the exceptional child (November 1971)

Responsive teaching: -focus on measurement and research in the classroom and the home (December 1971)

Physical educiation for the mentally retarded (January 1972)

Accountability in special education (February 1972)

Classroom forum (Monthly)

Resource materials (Monthly) 